Bulletin of the Natural History Museum, 2018, 11: 181-188.

Received 24 Jun 2018; Accepted 06 Nov 2018.

doi: $10.5937 / \mathrm{bnhmb} 1811181 \mathrm{~N}$

UDC: $582.572 .1 .088 .7(497.11)$

Short communication

\title{
ON THE PRESENCE OF PYRUS ×JORDANOVII IN SERBIA
}

\author{
MARJAN NIKETIĆ \\ Natural History Museum, 11000 Belgrade, Serbia, e-mail: mniketic@nhmbeo.rs
}

In the first edition of the Flora of Serbia (Jovanović 1972) three species were reported: $P$. domestica Medik., P. pyraster (L.) Burgsd. and $P$. amygdaliformis Vill. (= P. spinosa Forssk.). The first two taxa are hardly distinguished and according to current classification they are conspecific, within the $P$. communis L. [including two native spiny subspecies: $P$. $c$. subsp. pyraster (L.) Ehrh. and P. c. subsp. caucasica (Fed.) Browicz] (Browicz 1992, Kurtto 2009, Zohary et al. 2012, Kurtto et al. 2013, Bartolucci et al. 2018). Moreover, some recognize $P$. pyraster as a synonym of $P$. communis (POWO 2018). The domesticated type subspecies probably derived from two "eco-geographic wild subspecies" in Europe and W Asia (Zohary et al. 2012).

In addition to these taxa, Jovanović (1977) mentioned two species with tomentose leaves for Kosovo and E Serbia: P. elaeagrifolia Pall. and $P$. nivalis Jacq. The latter species was described from Austria and more widely known from southern parts of W, C and E Europe (Terpó \& Amaral 
Franco 1968, Aldasoro et al. 1996). However, its natural origin and/or distribution have been questioned (Koch 1869, Dostálek 1997, Fischer et al. 2008, Sisko et al. 2009, Kurtto 2009, Kurtto et al. 2013, Dimopoulos et al. 2013, Bartha \& Király 2015, POWO 2018). Dostálek (1997) and NPGS (2018) renewed the old opinion of Koch (1869) that $P$. nivalis is actually a nothospecies arose through the hybridisation of $P$. communis s.l. and $P$. elaeagrifolia s.l. which, according to Dostálek (1997) naturally has taken place in the sympatric area of the Balkan Peninsula (Bulgaria, SE Romania) and probably Anatolia. In fact, real hybrids are certainly limited to the contact zones in the east. In the rest of Europe their distribution was strongly affected by anthropogenic influence and could be treated as a fertile hybridogenous homoploid species $(2 n=34)$. Cultigenous or doubtfully native origin of $P$. nivalis is already presumed for Slovakia (Dostálek 1997), Austria (Fischer et al. 2008), Slovenija (Sisko et al. 2009) and Hungary (Bartha \& Király 2015). As a cultural pear of lesser value $P$. nivalis is rarely propagated and the introgression with local species and cultivars brought it almost to extinction (Dostálek 1997). The introgression into the genome of $P$. communis s.l. led to the forms of common pear with hairy leaves (Dostálek 1997) and consequently although the genome of $P$. nivalis is indeed present in Slovenia, its typical individuals have not been found (Sisko et al. 2009).

According to Dostálek (1997) the P. nivalis complex consists of hybrid swarms including several nothosubspecies and reverse hybrids originated from different subspecies of $P$. communis and $P$. elaeagrifolia. It also includes cultigenous $P$. austriaca A. Kern., which in his opinion should be derived from the type subspecies of $P$. communis and $P$. elaeagrifolia. Yet, it seems likely that this plant actually originates from a cross between $P$. communis subsp. pyraster and $P$. nivalis (Terpó 1960, Kurtto et al. 2013, Király 2015).

Dostálek also described some hybrids between $P$. communis s.l. and $P$. spinosa from Bulgaria (Dostálek 1980, 1984) which, unlike the previous ones, do not have grey-tomentose leaves beneath. It should be kept in mind that this author recognized two current subspecies of $P$. communis as a separate species, describing $P$. $\times$ jordanovii Dostálek $(P$. communis $\times P$. spinosa) and $P$. $\times$ velenovskyi Dostálek ( $P$. pyraster $\times P$. spinosa). In accordance with the current classification, it is necessary to propose a nomenclature novelty for the lattermost nothotaxon:

Pyrus ×jordanovii nothosubsp. velenovskyi (Dostálek) Niketić, stat. et comb. nov. (Figs 1-2)

[P. communis subsp. pyraster $(\mathrm{L}$.$) Ehrh. \times P$. spinosa Forssk.]

$\equiv P$. $\times$ velenovskyi Dostálek $[P$. pyraster L. $\times$ P. spinosa Forssk.], Folia Geobot. Phytotax. 19: 91 [basionym]. 
The first record of this hybrid in Serbia was previously unofficially mentioned for E Serbia (Jelašnica Gorge in vicinity of Niš) under the misapplied name $P$. nivalis (Niketić 1986). About five adult trees were found on the right (Klisura - Ploča) and one of the left (Inatovac - Kulina) slope of the gorge. One exsiccatus was collected after the fall of the leaves in autumn:

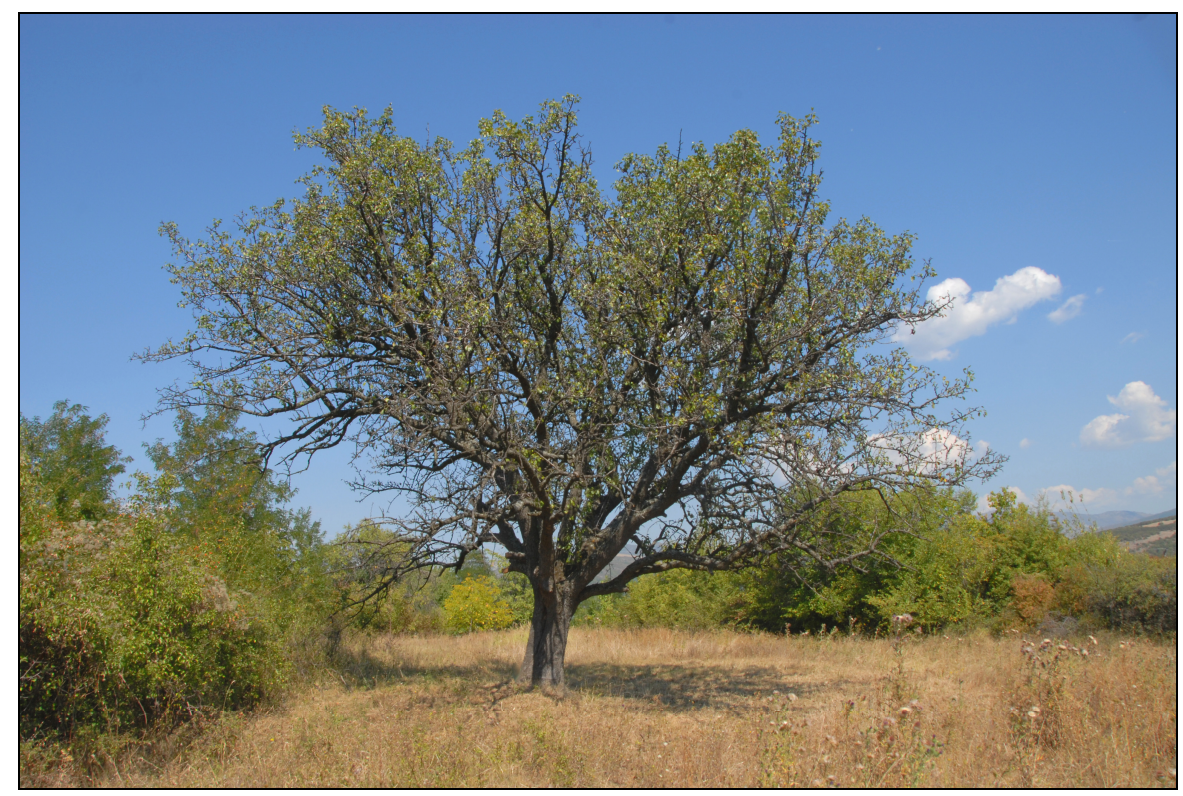

Fig. 1 - Pyrus ×jordanovii nothosubsp. velenovskyi (Dostálek) Niketić in Jelašnica Gorge - habitus.

E Serbia, Niš, Jelašnica Gorge, 200-450 m, Exp. S, limestone, forest and bushes and forest margins, together with " $P$. pyraster and $P$. spinosa", MGRS 34T EN89, coll. et det. M. Niketić 07-Nov-1989 (BEO 80000) (Fig. 3).

The shape and hairiness of the leaves completely correspond to the specimens described and illustrated in Dostálek (1980). It is interesting that some trees produce fruits (Fig. 2b), analogous to hybrids in the $P$. nivalis complex.

Given that the presence of $P$. elaeagrifolia and its descendant, $P$. nivalis, has not yet been confirmed for the flora of Serbia (Kurtto et al. 2013), it is possible to suppose that earlier records for $P$. nivalis (Jovanović 1977) actually refer to $P$. xjordanovii nothosubsp. velenovskyi. Additional research is needed to confirm this presumption. Generally, data on the presence of $P$. nivalis on the Balkan peninsula are contradictory. According to Terpó \& Amaral Franco 1968 this species is reported for Ex-Yugoslavia, Bulgaria and Greece. Its presence is also confirmed for Bulgaria (Vălev 

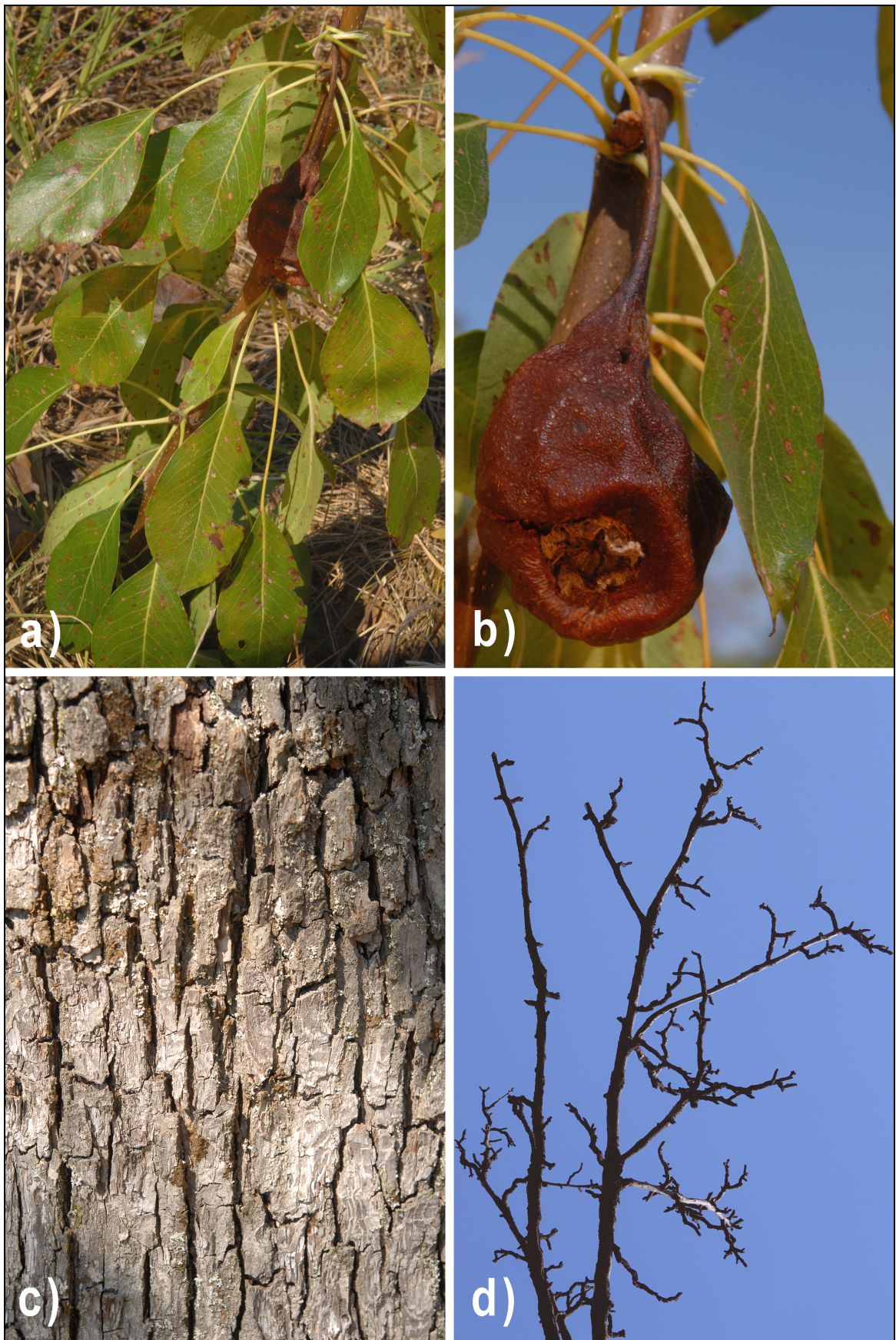

Fig. 2 - Pyrus ×jordanovii nothosubsp. velenovskyi (Dostálek) Niketić in Jelašnica Gorge: a) branches with leaves; b) dried fruit (pear) and leaves; c) tree bark; d) dried branches. 


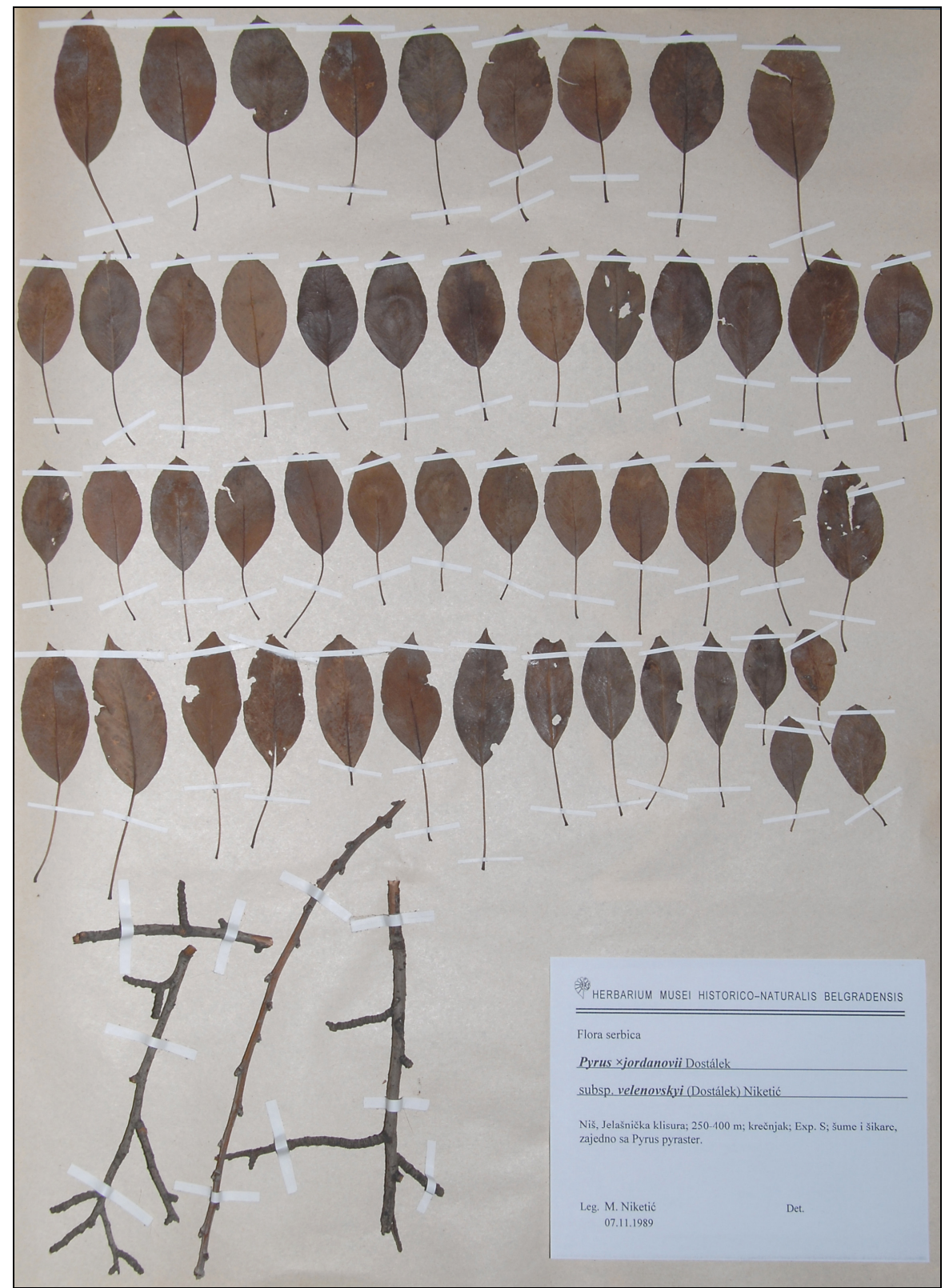

Fig. 3 - Pyrus ×jordanovii nothosubsp. velenovskyi (Dostálek) Niketić from the Jelašnica Gorge (BEO 80000).

1973, Dostálek 1997), but not for the Balkan Peninsula (Kurtto et al. 2013) and Greece (Dimopoulos et al. 2013). From the area of the Ex-Yugoslavia species is surely present in Slovenia (Sisko et al. 2009) and N Croatia (Slavonija) (Kitaibel 1864), including P. austriaca (Király 2015). 


\section{CONCLUSION}

A nothosubspecies of pear in the new combination Pyrus $\times$ jordanovii nothosubsp. velenovskyi (Dostálek) Niketić [P. communis subsp. pyraster (L.) Ehrh. $\times$ P. spinosa Forssk.] is recorded for the first time for the flora of Serbia. It is possible that some earlier records for the presence of $P$. nivalis actually refer to this taxon.

\section{REFERENCES}

Aldasoro, J. J., Aedo, C., Muñoz Garmendia, F. (1996): The genus Pyrus L. (Rosaceae) in south-west Europe and North Afkica. - Botanical Journal of the Linnean Society 121: 143-158.

Bartha, D., Király, G. (eds) (2015): Distribution atlas of vascular plants of Hungary. - University of West Hungary Press, Sopron.

Bartolucci, F., Peruzzi, L., Galasso, G., Albano, A., Alessandrini, A., Ardenghi, N. M. G., Astuti, G., Bacchetta, G., Ballelli, S., Banfi, E., Barberis, G., Bernardo, L., Bouvet, D., Bovio, M., Cecchi, L., Di Pietro, R., Dominao, G., Fascetti, S., Fenug, G., Festi, F., Foggi, B., Gallo, L., Gottschlich, G., Gubellini, L., Iamonico, D., Iberite, M., Jiménez-Mejías, P., Lattanzi, E., Marchetti, D., Martinetto, E., Masin, R. R., Medagli, P., Passalacqua, N. G., Peccenini, S., Pennesi, R., Pierini, B., Poldini, L., Prosser, F., Raimondo, F. M., RomaMarzio, F., Rosati, L., Santangelo, A., Scoppola, A., Scortegagna, S., Selvaggi, A., Selvi, F., Soldano, A., Stinca, A., Wagensommer, R. P., Wilhalm, T., Conti, F. (2018): An updated checklist of the vascular flora native to Italy. Plant Biosystems 152(2): 179-303.

Browicz, K. (1992): Chorology of trees and shrubs in southwest Asia and adjacent regions. - Institute of Dendrology, Polish Academy of Sciences, Kórnik, Poland.

Dimopoulos, P., Raus, T., Bergmeier, E., Constantinidis, T., Iatrou, G., Kokkini, S., Strid, A,. Tzanoudakis, D. (2013): Vascular Plants of Greece. An annotated checklist: 372 pp. - Botanic Garden and Botanical Museum Berlin-Dahlem, Berlin, Hellenic Botanical Society, Athens.

Dostálek, J. (1980): Pyrus spinosa und ihre Hybriden in Südwestbulgarien. - Folia geobotanica et phytotaxonomica 15: 59-73.

Dostálek, J. (1984): Hybriden von Pyrus spinosa. - Folia geobotanica et phytotaxonomica 19: 89-93.

Dostálek, J. (1997): Pyrus elaeagrifolia und ihre Hybriden. - Feddes Repertorium 108(5-6): 345-360.

Fischer, M., Oswald, K., Adler, W. (2008): Exkursions flora für Österreich, Liechtenstein und Südtirol, ed. 3. - Biologiezentrum der Oberösterreichischen Landesmuseen, Linz. 
Jovanović, B. (1972): Fam. Malaceae Lois.-Deslongch. In: Josifović, M. (ed.): Flora SR Srbije 4: 127-178. - Serbian Academy of Sciences and Arts, Belgrade. [in Serbian]

Jovanović, B. (1977): Fam. Malaceae. In: Josifović, M. (ed.): Flora SR Srbije Suplement 9: 110-111. - Serbian Academy of Sciences and Arts, Belgrade. [in Serbian]

Kurtto, A. (2009): Rosaceae (pro parte majore). In: Euro+Med Plantbase - the information resource for Euro-Mediterranean plant diversity. [http://ww2. bgbm.org/EuroPlusMed/PTaxonDetail.asp?NameCache=Rosaceae\&PTRefFk= 7300000] (retrieved October $16^{\text {th }} 2018$ )

Kurtto, A., Sennikov, A. N., Lampinen, R. (eds) (2013): Atlas Florae Europaeae. Distribution of Vascular Plants in Europe 16. Rosaceae (Cydonia to Prunus). The Committee for Mapping the Flora of Europe, Societas Biologica Fennica, Vanamo, Helsinki.

Király, G. (2015): Pyrus austriaca A. Kern. In: Raab-Straube, E. von \& Raus, Th. (ed.) (2015) - Euro+Med-Checklist Notulae, 4 - Willdenowia 45(1): 119-129.

Kitaibel, P. (1864): Additamenta ad Floram Hungaricam. - Linnaea 32(4-5): 305-642.

Koch, K. (1869): Dendrologie; Bäume, Sträucher und Halbsträucher, welche in Mittel- und Nord- Europa im Freien kultivirt werden. - Ferdinand Enke, Erlangen.

Niketić, M. (1986): Fitogeografske karakteristike Jelašničke klisure kod Niša. Unverzitet u Beogradu, Prirodno-matematički fakultet, Odsek za biološke nauke, Beograd. (graduate work, manuscr.) [in Serbian]

NPGS (2018): U.S. National Plant Germplasm System. - United States Department of Agriculture. Agricultural Research Service. [https://www.ars-grin.gov/ npgs/] (retrieved October $16^{\text {th }} 2018$ )

POWO (2018): Plants of the World Online. - Royal Botanical Garden Kew. [http://powo.science. kew.org] (retrieved October $16^{\text {th }} 2018$ )

Sisko, M., Javornik, B., Siftar, A., Ivancic, A. (2009): Genetic Relationships among Slovenian Pears Assessed by Molecular Markers. - Journal of the American Society for Horticultural Science 134(1): 97-108.

Terpó, A. (1960): Magyarország vadkörtéi (Pyri Hungariae). - Kertészeti és Szőlészeti Főiskola Évkönyve 22: 1-258.

Terpó, A., Amaral Franco, J. (1968): Pyrus L. In: Tutin, T. G., Heywood, V. H., Burges, N. A., Moore, D. M., Valentine, D. H., Walters, S. M., Webb, D. A. (eds): Flora Europaea 2: 313. - University Press, Cambridge.

Vălev, S. (1973): In: Jordanov, D. (ed.): Flora Reipublicae Popularis Bulgaricae 5: 335-339.

Zohary, D., Hopf, M., Weiss, E. (2012): Domestication of Plants in the Old World: The Origin and Spread of Domesticated Plants in Southwest Asia, Europe, and the Mediterranean Basin, ed. 4. - University Press, Oxford. 


\title{
О ПРИСУСТВУ PYRUS ×JORDANOVII У СРБИJИ
}

\author{
МАРЈАН НИКЕТИЋ
}

\section{Р Е 3 И М Е}

Нотоподврста дивље крушке у новој комбинацији Pyrus ×jordanovii nothosubsp. velenovskyi (Dostálek) Niketić $[P$. communis subsp. pyraster (L.) Ehrh. $\times$ P. spinosa Forssk.] констатована је по први пут за флору Србије. Могуће је да неки ранији подаци о присуству врсте $P$. nivalis заправо одговарају овом таксону. 